\title{
Comparison between pine bark and coconut husk sorption capacity of metals and nitrate when mixed with sewage sludge
}

\author{
L. Hernández-Apaolaza ，F. Guerrero \\ Agricultural Chemistry Department, Universidad Autónoma de Madrid, Francisco Tomás y Valiente 7, 28049 Madrid, Spain \\ Soil Department, ETSIA, Universidad Politécnica de Madrid, Avda, Complutense s/n, 28040 Madrid, Spain
}

\begin{abstract}
Waste products such as biosolids and wood wastes have been frequently used in container production of plants. The use of biosolids in agriculture is a beneficial mean of recycling the by-products of waste-water treatment. However, care must be taken to avoid environmental or human health problems via run-off and leaching.

The objective of this work is to compare the retention capacity of cadmium, lead, zinc and nitrate between pine bark (PB) and coconut fibre $(F)$ when mixed with increasing amounts of composted sewage sludge (CSS) $(0 \%, 15 \%$ and $30 \%$ (v/v)). Substrates were packed into leaching columns and irrigated with deionised water every 2 days. Leachates were collected during $1 \mathrm{month}$, and nitrate, $\mathrm{Zn}, \mathrm{Cd}, \mathrm{Pb}, \mathrm{EC}$ and $\mathrm{pH}$ were monitored along the experiment. $\mathrm{PB}$ columns leached lower amount of nitrate than the coconut fibre ones. The same trend was observed for $\mathrm{Zn}, \mathrm{Cd}$ and $\mathrm{Pb}$. It could be said, that in order to minimize the environmental risks of using sewage sludges our results indicate that it is preferred to mix the sludge with pine bark instead than with coconut husk.
\end{abstract}

Keywords: Pine bark; Coconut husk; Biosolids; Leaching

\section{Introduction}

Waste products such as biosolids (Gouin, 1993; Ingelmo et al., 1998; Guerrero et al., 2002) and wood wastes (Hicklenton et al., 2001; Chen et al., 2002) have been frequently used in container production of ornamental trees, shrubs and perennial plants. Nowadays other materials have been used as substrate, for example coconut fibres, because they have many characteristics in common with peat (Lennartsson, 1997). During the past few years this material has become commercially popular, and it is now being successfully used in different parts of the world as peat substitute for container-grown ornamental plants (Handreck, 1993; Stamps and Evans, 1997; Offord et al., 1998; Noguera et al., 2000; Abad et al., 2002).
The use of biosolids in agriculture is a beneficial mean of recycling the by-products of waste-water treatment as they contain plant nutrients and organic matter. However, care must be taken to ensure that use of biosolids in agriculture does not lead to environmental or human health problems via run-off and leaching of nutrients (especially nitrate and phosphate), pathogens, heavy metals and organic contaminants to surface or groundwater (Cooke et al., 2001).

Historically, strategies for application of animal manures have been based on meeting the nitrogen needs of crops to minimise nitrate loss by leaching (Sharpley et al., 1994). Excessive application rates, or inappropriate timing of application, can cause a significant threat to water quality (Shreve et al., 1995; Sharpley and Menzel, 1997). Nitrate is readily soluble and easily leached from soils (Kessavalou et al., 1996).

Concentrations of nutrients in biosolids vary both over time and between treatment plants, depending on the treatment process and the waste-water source (Smith, 1996), 
this fact may influence nutrient loss. For example, the greater the proportion of nitrogen presents as $\mathrm{NH}_{4}^{+}-\mathrm{N}$, the greater the potential for nitrate leaching (Shepherd, 1996; Smith et al., 1998a). Composting sewage sludge would also be expected to reduce nitrate leaching because mature composts contain relatively low amounts of mineral nitrogen, and are highly stabilised and resist further mineralisation on application to the soil (Smith et al., 1998b). Hazardous substances may be released from sewage sludge when large quantities are deposited for long periods and may percolate through the soil layers and reach the groundwater (Vanni et al., 1994; Cortés et al., 1992). There is an interest in following the fate of heavy metals in the environment because these elements continue to reach groundwaters (Jorgensen, 1976; Berthet et al., 1989).

In Europe there is an increasing pressure to reduce the leachates from horticultural crops for environmental reasons (Guimera et al., 1995). Therefore, it is necessary to improve commercial nursery practices to control the substrate solution.

Leaching tests are widely used for the assessment of the release of contaminants from different matrices. The release of contaminants from waste is influenced by a large number of physical (e.g. particle size, temperature, mode of contact with water and porosity) and chemical (e.g. $\mathrm{pH}$, redox, sorption properties, complexing agents and reaction kinetics) parameters. A variety of test procedures are available to characterise materials with respect to their leaching behaviour (Quevauviller et al., 1996). Fytianos et al. (1998) by using batch experiments concluded that the leached amounts for the sewage sludge examined metals followed the order: $\mathrm{Cd}>\mathrm{Zn}>\mathrm{Pb}>\mathrm{Fe}>\mathrm{Mn}$, and, as expected, when $\mathrm{pH}$ decreased, metal concentrations measured in the leachate increased.

The idea of considering the agricultural residues as ion exchangers has been investigated since the beginning of 1970s. Due to their large availability, interesting is growing especially over the last decade (Laszlo, 1996; Manju et al., 1998). Basically, two-thirds of the agricultural residues are composed of polysaccharides (cellulose and hemicelluloses) (Sjöström and Alen, 1999). Cellulose is the most abundant natural polymer and has three reactive hydroxyl groups in every constitutional glucose unit, but no correlation was found by Orlando et al. (2002) between the maximum nitrate adsorption and the cellulose content. The same authors showed the higher nitrate adsorption capacity of pine bark $(1.06 \mathrm{mmol} / \mathrm{g})$ in comparison with the coconut husk $(0.89 \mathrm{mmol} / \mathrm{g})$.

The objective of this work is to compare the ion adsorption capacity of two different substrates, pine bark and coconut husk, when mixed with composted sewage sludge. The high retention of ions will minimize environmental risk of releasing contaminants to the environment when those residues are use with agricultural purposes.

\section{Methods}

The substrates tested were pine bark and coconut fibre mixed with increasingly amounts of composted sewage sludge. Biosolid was mixed with both substrates at rates of $0 \%, 15 \%$ and $30 \%(\mathrm{v} / \mathrm{v})$ of sludge, homogenised and carefully repacked into glass columns $(20 \times 5 \mathrm{~cm})$. Initial characteristics of the substrates are shown in Tables 1 and 2 . The commercially valuable composted sewage sludge (CSS) was produced from a mixture of sawdust and anaerobically digested sewage sludge (volume ratio of $0.2: 1$ ) by the aerated-pile method. Three columns per treatment were located in randomized blocks and irrigated with $100 \mathrm{ml}$ of deionised water every two days. Leachates were collected and their volume measured. Nitrate and $\mathrm{pH}$ of the leachates were determined with an Orion Research Ion Analyzer 920A by using selective electrodes. Electrical conductivity (EC) was determined with an Orion Conductivimeter and metal content was assessed by voltamperometry, due to their low concentrations in leachates (Metrohm VA 646 y Stand VA 647).

Table 2

Initial characteristics of the substrates tested

\begin{tabular}{llllll}
\hline Substrate & $\mathrm{pH}$ & $\mathrm{EC}(\mu \mathrm{S} / \mathrm{cm})$ & OMox $(\%)$ & TOM $(\%)$ & Nkj $(\%)$ \\
\hline $\mathrm{PB}$ & $7.0 \mathrm{cb}$ & $1937 \mathrm{c}$ & $39.3 \mathrm{~b}$ & $53.3 \mathrm{~b}$ & $0.43 \mathrm{f}$ \\
$\mathrm{PB}+15 \% \mathrm{CSS}$ & $7.2 \mathrm{~b}$ & $6157 \mathrm{~b}$ & $32.6 \mathrm{c}$ & $45.2 \mathrm{c}$ & $0.89 \mathrm{~d}$ \\
$\mathrm{~PB}+30 \% \mathrm{CSS}$ & $7.6 \mathrm{a}$ & $8237 \mathrm{a}$ & $29.3 \mathrm{c}$ & $42.5 \mathrm{~d}$ & $1.25 \mathrm{c}$ \\
$\mathrm{F}$ & $6.1 \mathrm{~d}$ & $1343 \mathrm{c}$ & $46.0 \mathrm{a}$ & $85.6 \mathrm{a}$ & $0.71 \mathrm{e}$ \\
$\mathrm{F}+15 \% \mathrm{CSS}$ & $7.1 \mathrm{cb}$ & $5313 \mathrm{~b}$ & $42.1 \mathrm{ab}$ & $53.9 \mathrm{~b}$ & $1.59 \mathrm{~b}$ \\
$\mathrm{~F}+30 \% \mathrm{CSS}$ & $7.0 \mathrm{c}$ & $9350 \mathrm{a}$ & $34.3 \mathrm{c}$ & $43.9 \mathrm{~cd}$ & $2.05 \mathrm{a}$ \\
\hline
\end{tabular}

Table 1

Main physical characteristics of substrates

\begin{tabular}{|c|c|c|c|c|c|c|c|}
\hline Substrate & $\begin{array}{l}\text { Particle density } \\
\left(\mathrm{kg} / \mathrm{m}^{3}\right)\end{array}$ & $\begin{array}{l}\text { Bulk density } \\
\left(\mathrm{kg} / \mathrm{m}^{3}\right)\end{array}$ & $\begin{array}{l}\text { Porosity } \\
(\% \mathrm{v} / \mathrm{v})\end{array}$ & $\begin{array}{l}\text { Airspace }_{10} \\
(\% \mathrm{v} / \mathrm{v})\end{array}$ & $\begin{array}{l}\mu \text { porosity }_{100} \\
(\% \mathrm{v} / \mathrm{v})\end{array}$ & $\begin{array}{l}\mathrm{AW}_{10-50} \\
(\% \mathrm{~V} / \mathrm{v})\end{array}$ & $\begin{array}{l}\mathrm{AW}_{50-100} \\
(\% \mathrm{v} / \mathrm{v})\end{array}$ \\
\hline PB & $1980 \mathrm{c}$ & $290 \mathrm{~b}$ & $85.4 \mathrm{~d}$ & $56 \mathrm{a}$ & $18 \mathrm{c}$ & $9.7 \mathrm{~b}$ & $3.3 \mathrm{a}$ \\
\hline & $\mathrm{PB}+15 \% \mathrm{CSS}$ & $2080 \mathrm{~b}$ & $410 \mathrm{a}$ & $80.3 \mathrm{e}$ & $44 \mathrm{~b}$ & $23 \mathrm{~b}$ & $9.9 \mathrm{~b}$ \\
\hline $4.7 \mathrm{a}$ & $\mathrm{PB}+30 \% \mathrm{CSS}$ & $2120 \mathrm{a}$ & $426 \mathrm{a}$ & $79.9 \mathrm{f}$ & $31 \mathrm{c}$ & $25 \mathrm{~b}$ & $19.2 \mathrm{a}$ \\
\hline $\mathrm{F}$ & $1580 \mathrm{~d}$ & $57 \mathrm{e}$ & $96.4 \mathrm{a}$ & $52 \mathrm{a}$ & $21 \mathrm{bc}$ & $16.6 \mathrm{a}$ & $6.6 \mathrm{a}$ \\
\hline $\mathrm{F}+15 \% \mathrm{CSS}$ & $1980 \mathrm{c}$ & $115 \mathrm{~d}$ & $94.2 \mathrm{~b}$ & $45 \mathrm{~b}$ & $24 \mathrm{~b}$ & $19.5 \mathrm{a}$ & $5.7 \mathrm{a}$ \\
\hline $\mathrm{F}+30 \% \mathrm{CSS}$ & $2100 \mathrm{ab}$ & $231 \mathrm{c}$ & $89.0 \mathrm{c}$ & $41 \mathrm{~b}$ & $32 \mathrm{a}$ & $14.4 \mathrm{ab}$ & $1.9 \mathrm{a}$ \\
\hline
\end{tabular}


The hydrophysical characteristics of the substrates were determined by using the method described by De Boodt and Verdonk (1972) and Bunt (1988) for measuring the water desorption curve of organic substrates. According to this method, porosity $(\% \mathrm{v} / \mathrm{v})$ is the total pore space determined at $0 \mathrm{~cm}$ water suction, Airspace $10(\% \mathrm{v} / \mathrm{v})$ is the difference in volume between porosity and the moisture content at $10 \mathrm{~cm}$ suction, and microporosity 100 is the moisture content $(\% \mathrm{v} / \mathrm{v})$ at $100 \mathrm{~cm}$ suction. Two intervals of available water (AW) commonly used for horticultural purposes (De Boodt et al., 1974) were also determined. $A W_{10-50}(\% \mathrm{v} / \mathrm{v})$ is the water released from the substrate when the suction increases from 10 to $50 \mathrm{~cm}$, and $\mathrm{AW}_{50-100}(\% \mathrm{v} / \mathrm{v})$ is the water released from the substrate when the suction increase from 50 to $100 \mathrm{~cm}$ water tension.

Electrical conductivity (EC) and substrate $\mathrm{pH}$ were determined in the saturated paste extract with an Orion Conductivimeter and an Orion Research Ion Analyzer $920 \mathrm{~A} \mathrm{pH}$-meter equipped with a $\mathrm{pH}$-glass electrode, respectively, as well as the nutrient content by Atomic Absorption Spectrometry (AA, Perkin Elmer 2800). Total concentration of heavy metals was determined after digestion with $3: 1(\mathrm{v} / \mathrm{v})$ concentrated $\mathrm{HCl}-\mathrm{HNO}_{3}$ (aqua regia) by Atomic Absorption Spectrometry. Total organic matter (TOM), oxidized organic matter (OMox) and $\mathrm{N}$ by Kjeldahl digestion were also determined.

Results were statistically treated using the Statistical Package Social Science PC 13.0. Duncan's Multiple Range Test $(\alpha=0.01)$ was used to test for differences among means.

\section{Results}

\subsection{Physical characteristics}

The main physical characteristics of the substrates tested are shown in Table 1. Particle and bulk densities increased with the addition of sludge, as found in previous studies (Ingelmo et al., 1998; Chen et al., 2002; Guerrero et al., 2002; Hernández-Apaolaza et al., 2005, and present higher values for pine bark (PB) than for the coconut fibre $(\mathrm{F})$. When bulk density increases, the number of larger pores is reduced, and the root forces necessary for the deformation and displacement of substrate particles readily become limiting, and root elongation rates decrease (Taylor and Ratliff, 1969). But inhibition of root elongation is not necessarily correlated with inhibited uptake of mineral nutrients (Shierlaw and Alston, 1984). The porosity of the substrates decreased with the sludge addition, and it was higher for coco fibres media than for pine bark substrates. This fact was also reported by several authors (Ingelmo et al., 1998; Guerrero et al., 2002) for peat- and pine bark-sewage sludge substrates. Substrates with sludge showed higher microporosities than the pine bark and coconut fibre substrates. This fact is particularly interesting, since increases in microporosity improve rewettability of substrates due to both an increase in their water holding capacity and also a reduction of drainage (Beardsell and Nichols, 1982). Available water between 10 and $50 \mathrm{~cm}$ of water column suction $\left(\mathrm{AW}_{10-50}\right)$ was, in general, higher for coconut fibre based substrates than for pine bark substrates, but $A W_{50-100}$ did not show any significant differences between them.

Although compost percentages affected some measured parameters, physical properties of the substrates were generally within the recommended ranges for production of ornamental plants (Bunt, 1988).

\section{2. $\mathrm{pH}$ and electrical conductivity}

Initial soluble salts contents of CSS-based media were very high (Table 2 ), and well above the $0.6-2.0 \mathrm{mS} \mathrm{cm}^{-1}$ recommended for healthy and vigorous growth of plants (Wright, 1986). Bark compost typically contributes with few soluble salts to growing media (Chong and Rinker, 1994), as well as coconut fibre, so the major contribution to the EC value was related with the sewage sludge compost addition. As expected, the EC decrease along the experiment for both pine bark and coconut fibre substrates. Pine bark based substrates showed pHs around 7.0 (Table 2) and the coconut fibre ones around $\mathrm{pH}$ 6.0, which are typical for these type of substrate (Abad et al., 2002) and adequate for woody plant container production. At the end of the experiment, no significant differences between substrates were found due to the successive watering with deionised water. Similar situation occurred with the electrical conductivity (Table 3 ).

\subsection{Chemical characteristics}

Oxidized and total organic matter content (Table 2) of either pine bark or coconut husk substrates decreased with the biosolid addition. The addition of the sludge increased notably the nitrogen content of the substrates, as it was expected, and the highest value corresponded to the $\mathrm{F}+30 \%$ CSS-mixture (Table 2).

Ingelmo et al. (1998) obtain optimal results for the Cupressus sempervirens growth using different substrates with biosolids as a component and with $\mathrm{C}: \mathrm{N}$ ratios around 25:1 and Guerrero et al. (2002) described an optimal growth of Pinus pinea and Cupressus arizonica with $C: N$ ratios much higher than 25:1. In the present study, pine bark and coconut fibre initial conditions shown very high $\mathrm{C}: \mathrm{N}$ ratios, but the biosolid addition reduced significantly this parameter, arising to optimal values as described in the references, giving a most stable substrate. The rest of the substrates shown acceptable $\mathrm{C}: \mathrm{N}$ values, except for

Table 3

Heavy metals content (Aqua regia extraction, $\mathrm{mg} / \mathrm{kg}$ dry matter)

\begin{tabular}{lllllll}
\hline Substrate & $\mathrm{Cd}$ & $\mathrm{Cr}$ & $\mathrm{Cu}$ & $\mathrm{Zn}$ & $\mathrm{Pb}$ & $\mathrm{Ni}$ \\
\hline $\mathrm{CSS}$ & $2.6 \pm 0.3$ & $744 \pm 2$ & $460 \pm 2$ & $1420 \pm 3$ & $352 \pm 2$ & $87.3 \pm 2.0$
\end{tabular}


the $\mathrm{F}+30 \% \mathrm{CSS}$-media, which shown lower values than the ones for a mature substrate.

\subsection{Nitrate and metals in leachates}

Pine bark columns leached lower amount of nitrate than the coconut fiber ones $(\mathrm{PB}+15 \% \mathrm{CSS}=1221 \mu \mathrm{g} / \mathrm{g}$ and $\mathrm{F}+15 \% \mathrm{CSS}=5049 \mu \mathrm{g} / \mathrm{g}$ ) (Fig. 1). Since no relevant $\mathrm{pH}$ differences were observed (Table 2), this could be due to the higher retention capacity of the pine bark. Orlando et al. (2002) pointed out the higher nitrate adsorption capacity of pine bark $(1.06 \mathrm{mmol} / \mathrm{g})$ in comparison with the coconut husk $(0.89 \mathrm{mmol} / \mathrm{g})$.

Cadmium leached (Fig. 2) increased extraordinarily in coconut fibre columns in comparison with pine bark columns $(\mathrm{PB}+15 \% \mathrm{CSS}=3.1 \mu \mathrm{g} / \mathrm{L}$ and $\mathrm{F}+15 \% \mathrm{CSS}=15.6$ $\mu \mathrm{g} / \mathrm{L} ; \quad \mathrm{PB}+30 \% \mathrm{CSS}=4.5 \mu \mathrm{g} / \mathrm{L} \quad$ and $\mathrm{F}+15 \% \mathrm{CSS}=$ $42.0 \mu \mathrm{g} / \mathrm{L}$ ). Al-Asheh and Duvnjak (1997) showed that pine bark sorbs cadmium from aqueous solutions and a decrease in the bark content with a constant cadmium concentration, or an increase in the cadmium concentration with a constant bark content, increased cadmium loading per unit weight of the adsorbent. Pine bark can also adsorb the following metals from aqueous solutions with the indicated order of capacity (mass basis): $\mathrm{Pb}^{2+}>\mathrm{Cd}^{2+}>$ $\mathrm{Cu}^{2+}>\mathrm{Ni}^{2+}$ (Al-Asheh and Duvnjak, 1997). The same trend was observed for $\mathrm{Zn}$ and $\mathrm{Pb}$ (Figs. 3 and 4).

Sorption of heavy metals by these materials might be attributed to their protein, carbohydrates and phenolic compounds (Friedman and Waiss, 1972) which have

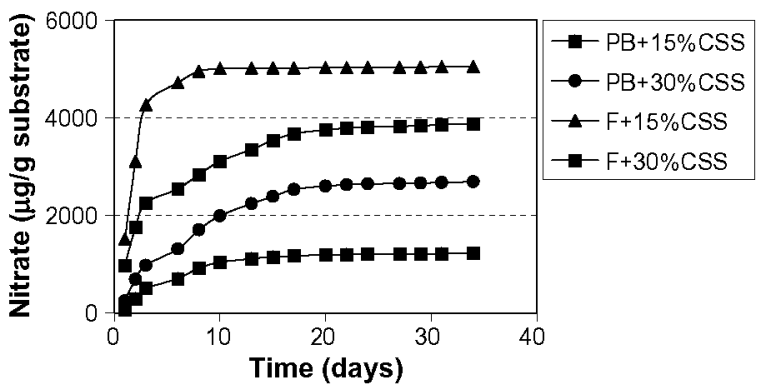

Fig. 1. Nitrate concentration ( $\mu \mathrm{g} / \mathrm{g}$ substrate) in leachates obtained from columns filled with pine bark (PB) or coconut husk (F) mixed with different amounts of composted sewage sludge (CSS).

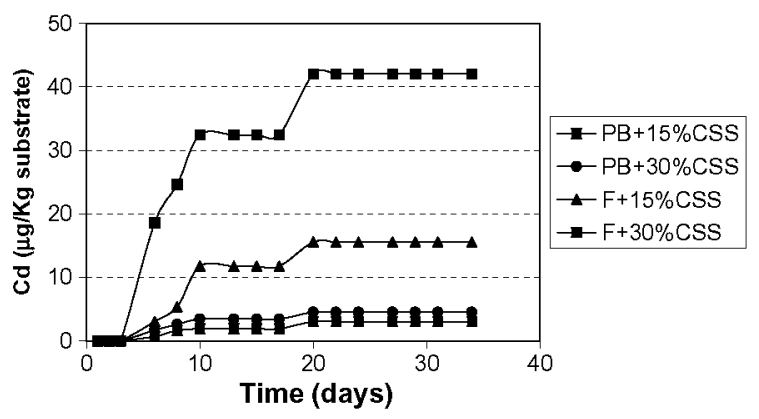

Fig. 2. Cadmium concentration ( $\mu \mathrm{g} / \mathrm{kg}$ substrate) in leachates.

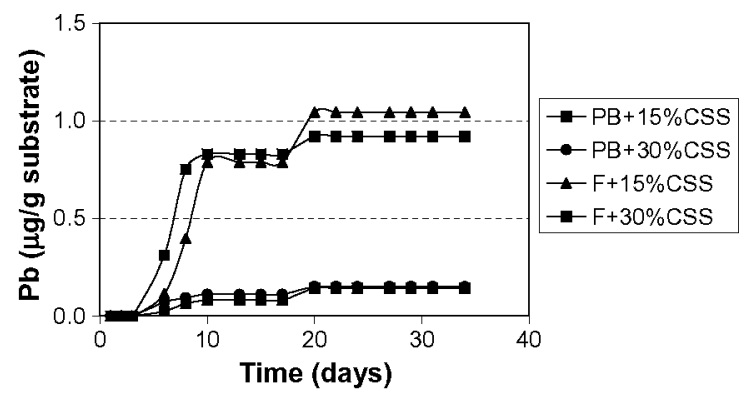

Fig. 3. Lead concentration ( $\mu \mathrm{g} / \mathrm{g}$ substrate) in leachates.

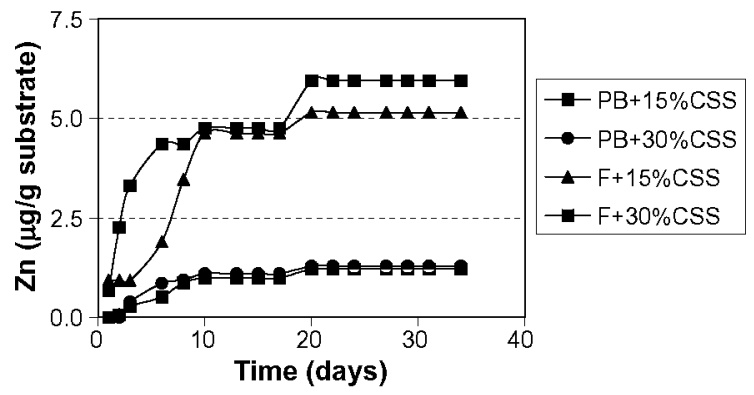

Fig. 4. Zinc concentration ( $\mu \mathrm{g} / \mathrm{g}$ substrate) in leachates.

metal-binding functional groups such as carboxyl, hydroxyl, sulphate, phosphate and amino groups (Kuyucak and Volesky, 1988). Salim et al. (1994) claimed that the loss of metal ions from the solutions in presence of agricultural materials may be due to the adsorption on surfaces and pores, and to complexation by these materials.

In conclusion, in order to minimize the environmental risks of using sewage sludges in agriculture our results indicate that it is preferred to mix the sludge with pine bark than with coconut husk.

\section{Acknowledgement}

This research was carried out with the financial support of Comunidad Autónoma de Madrid Project (No. 07M/ 0005/1999).

\section{References}

Abad, M., Noguera, P., Puchades, R., Maquieira, A., Noguera, V., 2002. Physico-chemical and chemical properties of some coconut coir dusts for use as a peat substitute for containerised ornamental plants. Bioresource Technol. 82, 241-245.

Al-Asheh, S., Duvnjak, Z., 1997. Sorption of cadmium and other heavy metals by pine bark. J. Hazard. Mater. 56, 35-51.

Beardsell, D.V., Nichols, D.G., 1982. Wettability properties of dried out nursery container media. Sci. Horticult. 17, 49-59.

Berthet, B., Amiard, J., Maillet, C., Pelletier, J., Lijklema, L. 1989. Fate of metals linked with sewage sludges or municipal refuses used as improvements in market gardening. Water Pollution Research and Control. Part 5. Oxford, UK. Pergamon/AWPRC.

Bunt, A.C., 1988. Media and Mixes for Container-grown Plants: A Manual on the Preparation and use of Growing Media for Growing Pot Plants, second ed. Unwin Hyman eds. Ltd, London. 
Chen, J., McConnell, D.B., Robinson, C.A., Caldwell, R.D., Huang, Y., 2002. Production and interior performances of tropical ornamental foliage plants grown in container substrates amended with compost. Compost Sci. Util. 10 (3), 217-225.

Chong, C., Rinker, D.L., 1994. Use of spent mushroom substrate for growing containerized woody ornamentals: an overview. Compost Sci. Util. 2, 45-53.

Cooke, C.M., Gove, L., Nicholson, F.A., Cook, H.F., Beck, A.J., 2001. Effect of drying and composting biosolids on the movement of nitrate and phosphate through repacked soil columns under steady-state hydrological conditions. Chemosphere 44, 797-804.

Cortés, A., Tapias, J., Folch, M., Salgot, M., 1992. Waste-water sludge quality for agricultural purposes, a comparison. Fresen. Environ. Bull. $1,262-267$

De Boodt, M., Verdonk, O., 1972. The physical properties of the substrates in horticulture. Acta Hort. 26, 37-44.

De Boodt, M., Verdonk, O., Cappaert, I., 1974. Method for measuring the water-release curve of organic substrates. Acta Hort. 37, 2054-2062.

Friedman, M., Waiss, A.C., 1972. Mercury uptake by selected agricultural products and by-products. Environ. Sci. Technol. 6 (5), 457-458.

Fytianos, K., Charantoni, E., Voudrias, E., 1998. Leaching of heavy metals from municipal sewage sludge. Environ. Int. 24, 467-475.

Gouin, F.R., 1993. Utilization of sewage sludge compost in horticulture. Hort. Technol. 3, 161-163.

Guerrero, F., Gascó, J.M., Hernández-Apaolaza, L., 2002. Use of pine bark and sewage sludge compost as components of substrates for Pinus pinea and Cupressus arizonica production. J. Plant Nutr. 25 (1), 129 141

Guimera, J., Marfa, O., Candela, L., Serrano, L., 1995. Nitrate leaching and strawberry production under drip irrigation management. Agric. Ecosyst. Environ. 56, 121-135.

Handreck, K.A., 1993. Properties of coir dust and its use in the formulation of soilless potting media. Commun. Soil Sci. Plant. Anal. $24,349-363$.

Hernández-Apaolaza, L., Gasco, A.M., Gasco, J.M., Guerrero, F., 2005. Reuse of waste materials as growing media for ornamental plants. Bioresource Technol. 96, 125-131.

Hicklenton, P.R., Rodd, V., Warman, P.R., 2001. The effectiveness and consistency of source-separated municipal solid waste and bark composts as components of container growing media. Scientia Horticulturae 91, 365-378

Ingelmo, F., Canet, R., Ibañez, M.A., Pomares, F., García, J., 1998. Use of MSW compost, dried sewage sludge and other wastes as partial substitutes for peat and soil. Bioresource Technol. 63, 123-129.

Jorgensen, S., 1976. An ecological model for heavy metal contamination of crops and groundwater from sludge application. Ecol. Model. 2, 5967.

Kessavalou, A., Doran, J.W., Powers, L., Kettler, T.A., Qian, J.H., 1996. Bromide and nitrogen-15 tracers of nitrate leaching under irrigated corn in central Nebraska. J. Environ. Qual. 25, 1008-1014.

Kuyucak, N., Volesky, B., 1988. Biosorbents for recovery of metals from industrial solutions. Biotechnol. Lett. 10 (2), 137-142.

Laszlo, J.A. 1996. Chemical strategies for producing anion exchangers from lignocellulosic residues to be used for removing textiles dyes from waste-water. In: Spec. Publ.-R. Soc. Chem. Ion Exchange Developments and Application, first ed., pp. 128-134.
Lennartsson, M. 1997. The peat conservation issue and the need for alternatives. In: Proceedings of the IPS International Peat Conference on Peat in Horticulture, Schmilewski, Amsterdam, pp. 112-121.

Manju, G.N., Raji, C., Anirudhan, T.S., 1998. Evaluation of coconut husk carbon for the removal of arsenic from water. Water Res. 32 (10), 3062-3070.

Noguera, P., Abad, M., Noguera, V., Puchades, R., Maquieira, A., 2000. Coconut coir waste, a new and viable ecologically-friendly peat substitute. Acta Hort. 517, 279-286.

Offord, C.A., Muir, S., Tyler, J.L., 1998. Growth of selected Australian plants in soilless media using coir as substitute for peat. Aust. J. Exp. Agr. 38, 879-887.

Orlando, U.S., Baes, A.U., Nishijima, W., Okada, M., 2002. Preparation of agricultural residue anion exchangers and its nitrate maximum adsorption capacity. Chemosphere 48, 1041-1046.

Quevauviller, P., van der Sloot, H., Muntau, H., Rauret, G., 1996. Conclusions of the workshop: Harmonization of leaching/extraction tests for environmental risk assessment. Sci. Total Environ. 178, 133139.

Salim, R., Al-Subu, M.M., Qashoa, S., 1994. Removal of lead from polluted water using decaying leaves. J. Environ. Sci. Health A 29 (10), $2087-2114$

Sharpley, A.N., Menzel, R.G., 1997. The impact of fertiliser phosphorus on the environment. Adv. Agron. 41, 297-324.

Sharpley, A.N., Chapra, S.C., Wedepohl, R., Sims, J.T., Daniel, T.C., Reddy, K.R., 1994. Managing agricultural phosphorus for protection of surface waters: issues and options. J. Environ. Qual. 23, 437-451.

Shepherd, M.A., 1996. Factors affecting nitrate leaching from sewage sludges applied to a sandy soil in arable agriculture. Agr. Ecosyst. Environ. 58, 171-185.

Shierlaw, J., Alston, A.M., 1984. Effect of soil compaction on root growth and uptake of phosphorous. Plant Soil 77, 15-28

Shreve, B.R., Moore Jr., P.A., Daniel, T.C., Edwards, D.R., Miller, D.M., 1995. Reduction of phosphorus in runoff from field-applied poultry litter using chemical amendments. J. Environ. Qual. 24, 106-111.

Sjöström, E., Alen, R., 1999. Analytical Methods in Wood Chemistry, Pulping and Papermaking. Springer, Berlin, ISBN 3-540-63102-X.

Smith, S.R., 1996. Agricultural Recycling of Sewage Sludge and the Environment. CAB International, Wallingford, Oxfordshire.

Smith, S.R., Woods, V., Evans, T.D., 1998a. Nitrate dynamics in biosolids-treated soils I. influence of biosolids type and soil type. Bioresource Technol. 66, 139-149.

Smith, S.R., Woods, V., Evans, T.D., 1998b. Nitrate dynamics in biosolids-treated soils II. thermal-time models of the different nitrogen pools. Bioresource Technol. 66, 151-160.

Stamps, R.H., Evans, M.R., 1997. Growth of Dieffenbachia maculata "Camille" in growing media containing Sphagnum peat or coconut coir dust. Hort. Sci. 32, 844-847.

Taylor, H.M., Ratliff, L.F., 1969. Root elongation rates of cotton and peanuts as a function of soil strength and soil water content. Soil Sci $108,113-119$

Vanni, A., Gennaro, M., Petruzzelli, G., Liberatori, A., 1994. Leachability of heavy metals in municipal sludge particulate. Environ. Technol. 15, $71-78$

Wright, R.D., 1986. Pour through nutrient extraction procedure. Hort Sci. 21, 227-229. 